\title{
Bacterial mobbing behavior: coordinated communal attack of Pseudomonas aeruginosa on a protozoan \\ predator
}

\author{
N. Shteindel ${ }^{1}$, Y. Gerchman ${ }^{2}$ \\ ${ }^{1}$ Department of Environmental and evolutionary biology, \\ University of Haifa, Haifa, Israel. \\ Email: nimrod.sh@gmail.com \\ ${ }^{2}$ The University of Haifa and Oranim College, Tivon, Israel.
}

Mobbing, a group attack of prey on predator, is a strategy enacted by many animal species. Here we report bacterial mobbing carried out by the bacterium Pseudomonas aeruginosa towards Acanthamoeba castellanii, a common bacterivore. This behavior consists of bacterial taxis towards the amoebae, adhesion en masse to amoebae cells, and eventual killing of the amoebae. Mobbing behavior transpires in second's timescale and responds to predator population density. A mutant defective in the production of a specific quorum sensing signal displays reduced adhesion to amoeba cells. This deficiency ameliorated by external addition of the missing signal molecule. The same quorum sensing mutant also expresses long term deficiency in its ability to cause amoeba death and shows higher susceptibility to predation, highlighting the importance of group coordination to mobbing and predation avoidance. These findings portray bacterial mobbing as a regulated and dynamic group behavior. 
Mobbing is a predation avoidance behavior, manifested as an attack on predator by a group of prey organisms[1]. Predation by bacterivores is a major selective force shaping bacterial evolution, leading to the development of many predation avoidance mechanism - increasing of size, either per cell or by microcolony formation, anti-predator toxin secreation and surface signal masking[2, 3]. Nevertheless, protozoan predation can be a fast process, with several to several thousand bacteria consumed every

\section{Methods}

\section{Strains, plasmids and culture conditions}

Pseudomonas aeruginosa PAO1 w.t and P. aeruginosa PAO1 $\Delta p q s \mathrm{~A}[9]$ carrying the pMRP9-1 plasmid[10, 11], encoding for Carbenicillin resistance and constitutive expression of $\mathrm{GFP}_{\text {mut2 }}$ (ref. 11) were cultivated in $50 \mathrm{ml}$ M9 medium $(47.75 \mathrm{mM}$ $\mathrm{Na}_{2} \mathrm{HPO}_{4}, 22.05 \mathrm{mM} \mathrm{KH} \mathrm{PO}_{4}$. $8.56 \mathrm{mM} \mathrm{NaCl}, 18.69 \mathrm{mM} \mathrm{NH} \mathrm{Cl}_{4}$, $2 \mathrm{mM} \mathrm{MgSO}_{4}, 0.1 \mathrm{mM} \mathrm{CaCl} 2$ ), $200 \mu \mathrm{g} / \mathrm{ml}$ Carbenicillin, 0.4\% 
period of 18 hours, centrifuged to separate (12,000 g, 1 minute), washed once in and re-suspended TBSS in a TRIS-buffered salts solution (TBSS) $(2 \mathrm{mM} \mathrm{KCl}, 1 \mathrm{mM} \mathrm{CaCl} 2,0.5 \mathrm{mM} \mathrm{MgCl} 2,1 \mathrm{mM}$ TRIS).

Acanthamoeba castellanii was cultured in PYG medium (ATCC 712) supplemented with $100 \mu \mathrm{g} / \mathrm{ml}$ Gentamicin, $10 \mathrm{ml}$ in a $50 \mathrm{ml}$ tissue culture treated culture flasks (Greiner, Germany) in $25^{\circ} \mathrm{C}$, static, for five days. The flask was shaken vigorously to separate the cells from the plastic surface; culture was transferred to 1.5 plastic micro tubes ( $1.5 \mathrm{ml}$ per tube) and centrifuged to separate the cells $(200 \mathrm{~g}, 30 \mathrm{sec})$ The culture was gradually transferred to TBSS medium, replacing 500, 1000, $1500 \mu \mathrm{L}$ of the medium in each tube in consecutive wash cycles, centrifuged once more and collected into $1 \mathrm{ml}$ of TBSS in a $10 \mathrm{~mm}$ glass tube. Culture density was determined by microscopy in a disposable penta-square counting chamber (Vacutest Kima, Italy) and diluted to the culture density indicated in each experiment.

\section{Microscopy of $P$. aeruginosa PAO1 attachment to amoeba} Ten $\mu \mathrm{L}$ of $5 \times 10^{5}$ cells $/ \mathrm{ml}$ amoeba culture in TBSS medium were added to a counting chamber and imaged using a fluorescence enable binocular system (Nikon SMZ18 fluorescence dissecting microscope connected to a Nikon DS-Fi3 camera, using the NIS elements software) in visible light and in green fluorescence. Fluorescence imaging setting: magnificationX12, exposure time 500 milliseconds, gain X14, field size 2880X2048 pixels, dynamic range of $3 \mathrm{X} 8$ bit. In this setting, using a plasmid that produces mild fluorescence, only aggregated bacteria can be seen. After imaging the amoebae in the absence of bacteria for a few minute, $10 \mu \mathrm{L}$ of 
fluorescently tagged $P$. aeruginosa PAO1 culture were added and photographed every 10 seconds for a period on 10 minutes.

\section{Effect of amoeba population density on $P$. aeruginosa attachment behavior}

Bacterial adhesion to amoebae was quantified using a kinetic assay in 96 well plate format[12] (figure $2 \mathrm{a}$ of this work). Amoeba culture in TBSS was diluted to $8 \times 10^{4}$ cells $/ \mathrm{ml}$ and $50 \mu \mathrm{L}$ were pipetted into the first row of a 96 well plate (clear tissue culture treated polystyrene, flat bottom, Jet-biofil, China), and diluted in a double dilution series using fresh TBSS. The $12^{\text {th }}$ column (no amoeba) was added with only $50 \mu \mathrm{L}$ TBSS. Amoebae were left to settle on the plate bottom for one hour prior to the addition of bacteria. Overnight culture of $P$. aeruginosa PAO1 was washed three times with TBSS, OD $600 \mathrm{~nm}$ adjusted to 0.1 (measured in 100 $\mu \mathrm{L}$ volume in a clear flat bottom 96 well plate) and supplemented with $1.6 \mathrm{mg} / \mathrm{ml}$ Red\#40 dye (Sigma, Israel). Fifty $\mu \mathrm{L}$ of this culture were pipetted to rows A-G of the plate containing the amoeba, row $\mathrm{H}$ pipetted with $50 \mu \mathrm{L}$ of TBSS supplemented with the dye to be used as blank. Pipetting of bacterial culture to the plate was carried out within 30 seconds, using an 8-channel pipetor. Final bacterial culture density was $\mathrm{OD}_{600 \mathrm{~nm}}=0.05$, final dye concentration $0.8 \mathrm{mg} / \mathrm{ml}$ and final amoebae counts $0,4,8,16,32$, 64, 125, 250, 500, 1000,2000 and 4000 amoebae per well. The plate was loaded into a multimode plate reader (Synergy HT, Biotek, USA) and read kinetically for bottom fluorescence (Excitation $485_{\mathrm{nm}} / 20$, Emission $528_{\mathrm{nm}} / 20$, Gain 60 ) for one hour in one minute intervals.

\section{$P$. aeruginosa taxis towards amoeba}


Taxis experiments were done using Corning ${ }^{\circledR}$ FluoroBlok ${ }^{\mathrm{TM}}$ HTS 24-well Multi-well Permeable Support System with $3.0 \mu \mathrm{m}$ high density PET intervening membrane (Corning, New York, USA) designed for cell migration assays. Pseudomonas aeruginosa and amoeba cultures were grown and prepared as described. Bacteria were diluted in TBSS to $\mathrm{OD}_{600 \mathrm{~nm}}=0.1$ and amoebae culture was diluted to $1 \times 10^{4}$ cells $/ \mathrm{ml}$. Amoeba culture $(750 \mu \mathrm{L})$ were added to the bottom chamber of columns 1-3 of the plate, and columns 4-6 were added with $750 \mu \mathrm{L}$ of TBSS buffer. The filter system was mounted onto the plate base and the plate was loaded onto the plate reader. The plate was read for bottom fluorescence (Excitation $485 \mathrm{~nm} / 20$, Emission $528 \mathrm{~nm} / 20$, gain 60 , used as blank reading) to obtain the base fluorescence without bacteria. Then top chambers were loaded, one at a time, with $100 \mu \mathrm{L}$ of the bacterial culture and read kinetically for bottom fluorescence every four seconds for a period of two minutes - appearance of fluorescence indicating the migration of bacteria from the upper chamber, through the membrane, to the bottom chamber.

\section{Modulation of $P$. aeruginosa adhesion behavior by amoebae} conditioned buffer

Adhesion of $P$. aeruginosa w.t. in the presence and absence of A. castellanii conditioned buffer was carried using kinetic assay in 96 well plate format as previously described. Amoebae were culture and washed as described earlier, diluted to 10000 cells per $\mathrm{ml}$ in TBSS medium and incubated in $25^{\circ} \mathrm{C}$ for 2 hours and separated by centrifugation (200 g, $1 \mathrm{~min}$ ). Buffer separated from amoebae culture and unconditioned buffer were pipetted into 96 well plate in $50 \mu \mathrm{L}$ volume. Fifty $\mu \mathrm{L}$ of w.t. PAO1 suspension, supplemented with RED\#40 prepared was added to each well, and bottom fluorescence was read kinetically as described earlier. 
Amoebae were cultured and transferred and diluted to $2 \times 10^{4}$ amoebae/ml as previously described. Fifty $\mu \mathrm{L}$ of this culture (1,000 amoeba per well) were pipetted to 48 wells of a flat bottom clear 96 well plate, the other half pipetted with sterile TBSS. GFPmut2 expressing $P$. aeruginosa PAO1, either w.t. or $\Delta p q s \mathrm{~A}$, were cultured, washed and diluted to $\mathrm{OD}_{600 \mathrm{~nm}}=0.1$ as described earlier, and added into wells with or without amoeba (14 replicates per treatment). Bottom fluorescence reading (Excitation $485_{\mathrm{nm}} / 20$,

\section{Effect of PQS concentration on $P$. aeruginosa attachment to} amoebae

Pseudomonas aeruginosa PQS (2-nonyl-3-hydroxy-4-Quinolone, Sigma, Israel) was dissolved in DMSO to $10 \mathrm{mM}$ concentration, diluted in TBSS medium in double dilution series, to concentrations of $20 \mu \mathrm{M}$ to $20 \mathrm{nM}$ per 96 -well plate well (11 concentrations + negative control; $25 \mu \mathrm{L}$ volume). Amoebae culture was prepared as previously described, diluted to 4,000 cells/ml, and added to all above wells, $25 \mu \mathrm{L}$ and 1,000 cells per well. $\mathrm{GFP}_{\text {mut2 }}$ expressing $P$. aeruginosa PAO1 $\Delta p q s \mathrm{~A}$ was cultivated and prepared as described earlier, diluted to $\mathrm{OD}_{600 \mathrm{~nm}}=0.1$ in TBSS and supplemented with $1.6 \mathrm{mg} / \mathrm{ml} \mathrm{Red \# 40.}$ Fifty $\mu \mathrm{L}$ of this bacterial culture was added to rows $A-G$ of the amoeba-PQS plate, to final volume of $100 \mu \mathrm{L}$, culture density of $\mathrm{OD}_{600 \mathrm{~nm}}=0.05$, dye concentration of $0.8 \mathrm{mg} / \mathrm{ml}, 1,000$ amoebae per 
well and $5 \mu \mathrm{M}$ to $5 \mathrm{nM}$ of PQS. Row $\mathrm{H}$ was added with dye supplemented TBSS and used as blanks. The plate was loaded to the plate reader and read for bottom fluorescence (Excitation $485_{\mathrm{nm}} / 20$, Emission $528_{\mathrm{nm}} / 20$, Gain 60 ) every minute for a period of one hour. The same experiment was conducted in the absence of amoebae (replaced with additional $25 \mu \mathrm{L}$ of TBSS per well).

\section{Effect of PQS signaling on amoebae killing}

PAO1 w.t. and $\triangle p q s \mathrm{~A}$ were cultured overnight in M9 medium. $E$. coli DH5 $\alpha$ was cultured in Lennox LB (Himedia, Mumbai, India). All strains were washed twice in M9 buffer, and diluted to $\mathrm{OD}_{600 \mathrm{~nm}}=5,2$ or 1 . Some of the PAO1 w.t. culture was separated, washed once in M9 buffer, transferred to $1.5 \mathrm{ml}$ plastic micro tubes and heat killed at $65^{\circ} \mathrm{C}$ for 20 minutes. A sample of the heat killed bacteria was plated on an LB plate to verify inactivation. Acanthamoeba castellanii was cultivated, washed and and diluted to $2 \times 10^{5}$ cells per ml. Twenty seven $\mu \mathrm{L}$ of amoeba suspension were pippeted to all cells of six counting chambers (Vacutest Kima, Italy) and $3 \mu \mathrm{L}$ of bacterial suspensions were added to final $\mathrm{OD}_{600 \mathrm{~nm}}=0.5,0.2$ and 0.1 , as well as heat killed w.t. at $\mathrm{OD}_{600 \mathrm{~nm}}=0.5$ and no bacteria control ( 5 replicates per treatment). The number of amoebae cell within the counting grid was counted, this measurement serving as $\mathrm{T}_{0}$. The counting cells were kept in a humidified chamber and counted again at 12, 24 and 36 hours.

\section{Results}

Live microscopy of GFP expressing $P$. aeruginosa shows adhesion to A. castellanii cells seconds after the introducing bacteria to the amoebae culture (Figure 1). 

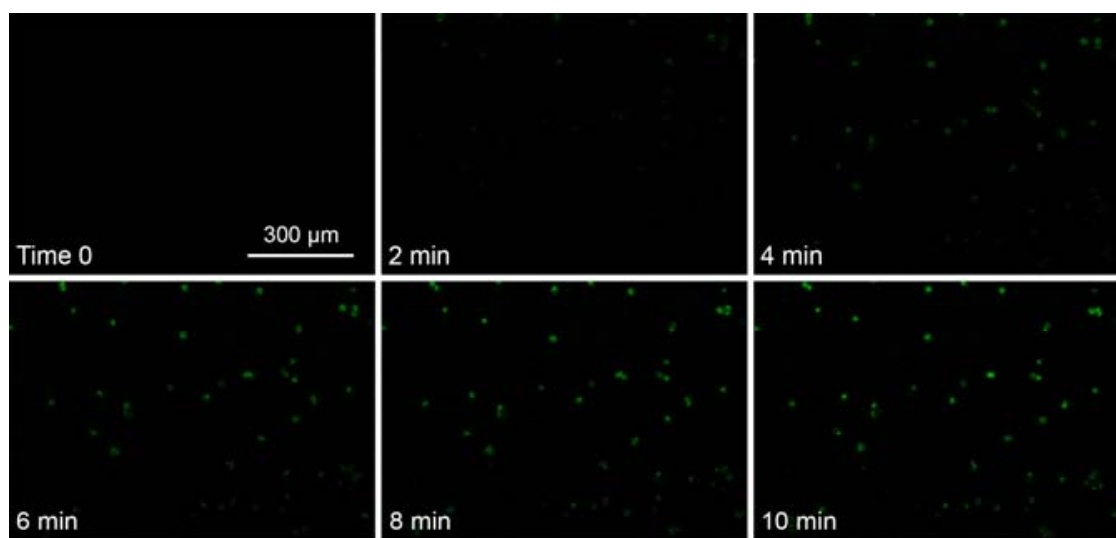

$4 \mathrm{~min}$
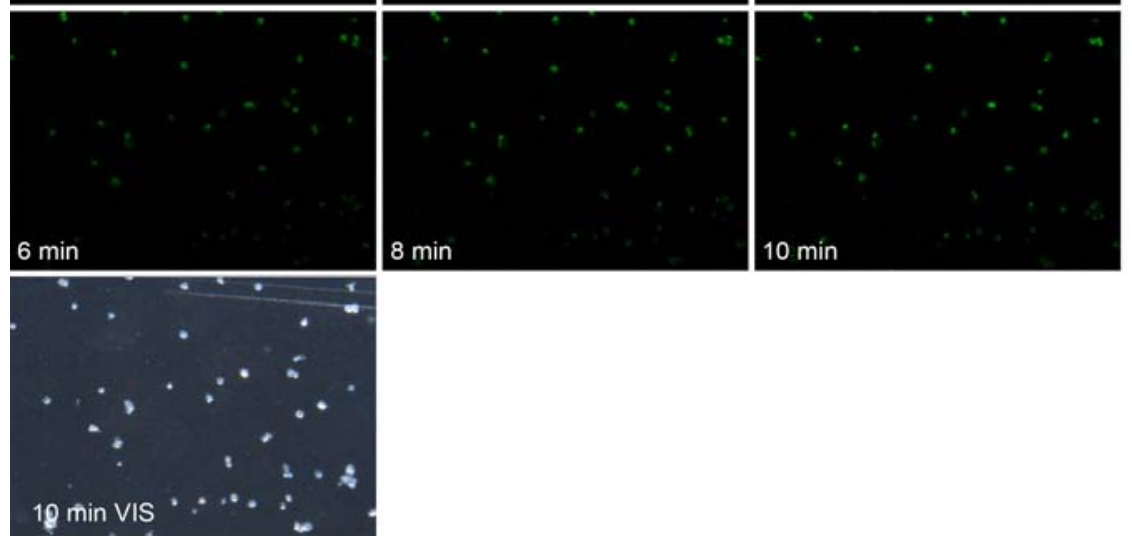

Figure 1 - Time laps of GFP expressing $P$. aeruginos $a$ adhesion to cells of $A$.

castellanii. Fluorescence intensity rise as bacteria aggregate on amoebae cells. Plateau is reached within 10 minutes.

Quantitative study of $P$. aeruginosa adhesion to the amoebae was conducted using bacterial kinetic adhesion assay in microtiter format[12] (figure 2a), measuring adhesion kinetics in various predator population densities. Initial attachment rates (Figure 2b; first five minutes) are in linear correlation with amoebae 
a.

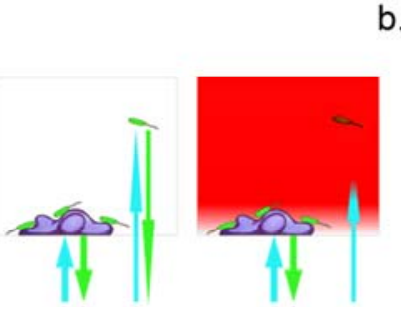
medium (Figure 3c). b.

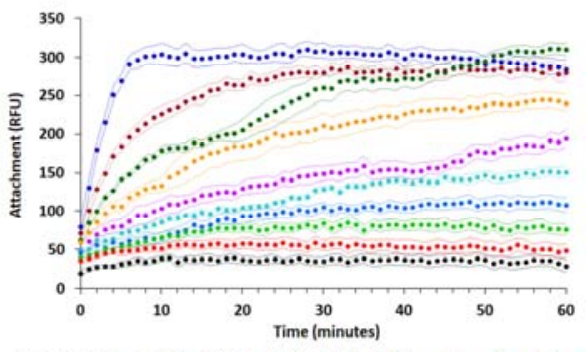

Amoebae/well $\cdot 4000 \cdot 2000 \cdot 1000 \cdot 500 \cdot 250 \cdot 125 \cdot 64 \cdot 32 \cdot 4 \cdot 0$

Figure 2 - The effect of amoebae population density on $P$. aeruginosa adhesion kinetics. a. Illustration of bacterial adhesion kinetics in micro plate assay: fluorescent signal in the absence (left) and presence (right) of dye. Addition of the dye limits the depth of field to about $5 \mu \mathrm{m}$ from the bottom of the well, allowing the detection of adhered GFP expressing bacteria to the well bottom in real time. $b$. Adhesion kinetics of $P$. aeruginosa to amoeba on the bottom of the microtiter wells. $\mathrm{n}=7$ per for all treatments, dots signify measurements, flanking curves stand for \pm 1 S.D.

To test whether this predator effect on bacterial adhesion kinetics is based on taxis, we followed migration of fluorescent bacteria through a fluorescence blocking $3 \mu \mathrm{m}$ intervening membrane, in the presence and absence of amoebae in the bottom chamber (Figure 3a), using the Flouroblok ${ }^{\mathrm{TM}}$ system (Corning, New York, USA). Figure $3 \mathrm{~b}$ shows migration was faster in the presence of amoebae. The ability of $P$. aeruginosa to sense amoebae from distance using a soluble moiety is also supported by the modulation of bacterial adhesion behavior by amoebae conditioned 
a.

c.
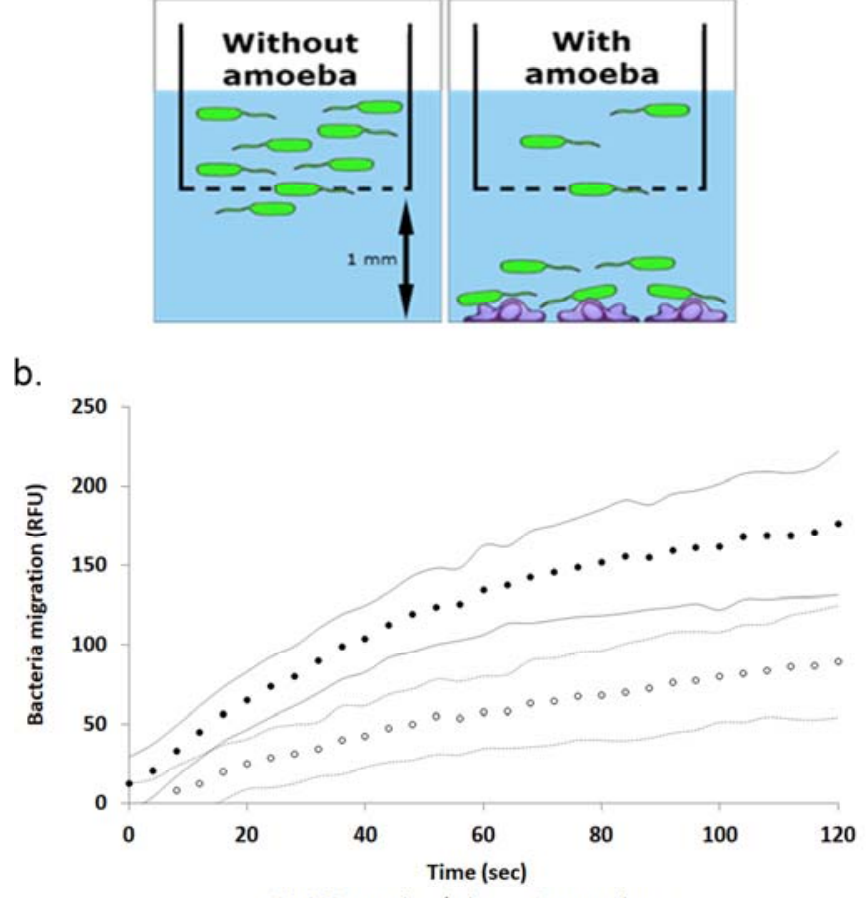

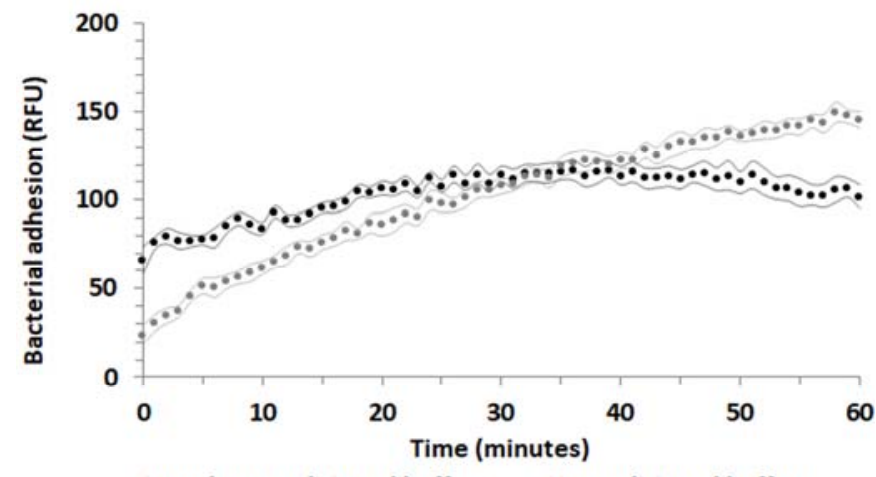

- Amoebae conditioned buffer - Unconditioned buffer

Figure 3 - Pseudomonas

aeruginosa taxis towards

amoebae a. Illustration of

measurement of bacterial

migration through a

fluorescence blocking filter

in the absence (left) and

presence (right) of amoebae

in the bottom chamber. $b$.

Bacterial migration kinetics in the absence (white dots) and presence (black dots) of 10,000 amoebae/ml in the bottom chamber. $\mathrm{n}=9$ for all treatments c. Effect of amoebae conditioned buffer on $P$. aeruginosa adhesion kinetics, $n=7$. Dots represent measurements, flanking curves stand for \pm 1 SD.

Mobbing behavior requires an individual not only to sense and a predator, but also to coordinate and synchronize its attack with other individuals, which in bacteria is often facilitated by QS systems. Indeed, P. aeruginosa $\triangle p q s \mathrm{~A}$ mutant, deficient in $\mathrm{PQS}$ production but able to sense and respond to it, exhibits slow adhesion to amoebae cells (Figure $4 b$ ). The addition of PQS restores within seconds some of the mutant adhesion behavior, in a dose dependent manner, but only in the presence of amoebae (Figure $4 \mathrm{a}, 4 \mathrm{c}$ ). Ten $\mathrm{nM}$ of PQS produce a 

tail $\mathrm{t}$ test, $\mathrm{t}_{6}=-1.89, \mathrm{p}=0.042$ ). Full data set of PQS concentrations is

a.

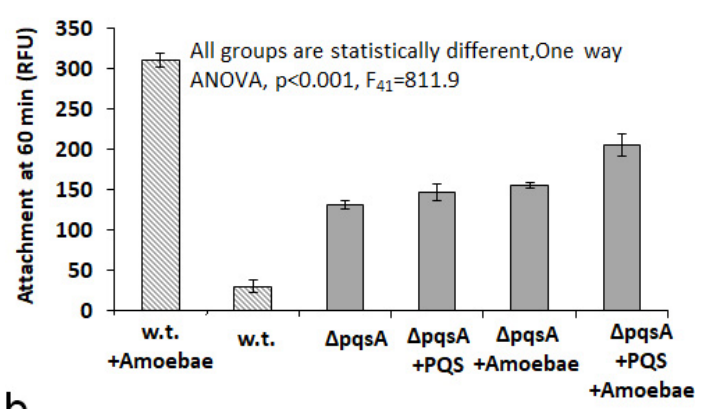

$$
\text { b. }
$$

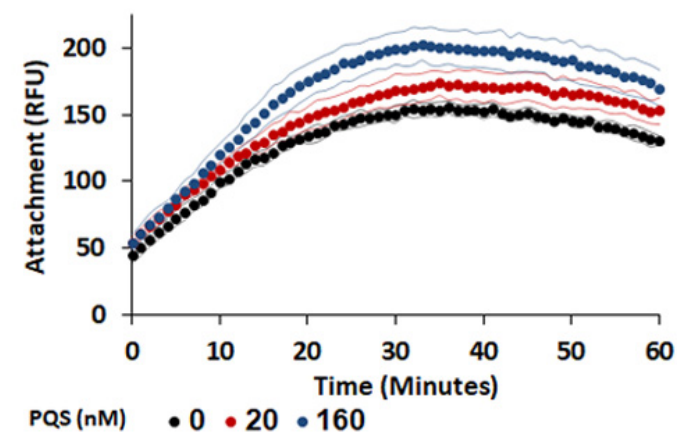

C.

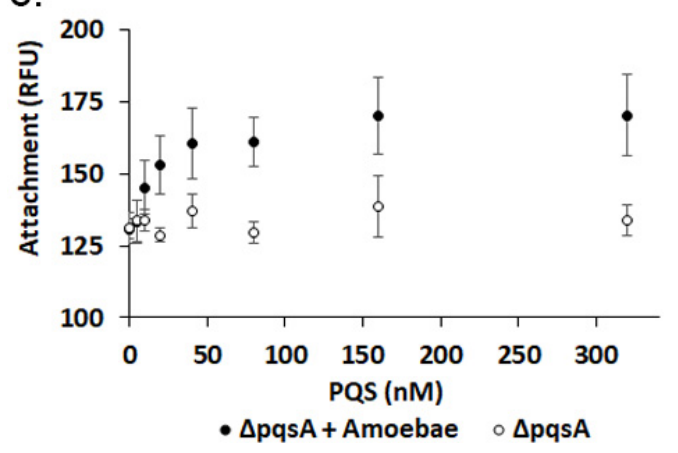
into hours and days timescales. Amoebae predation affects both w.t. and 
318

319

320

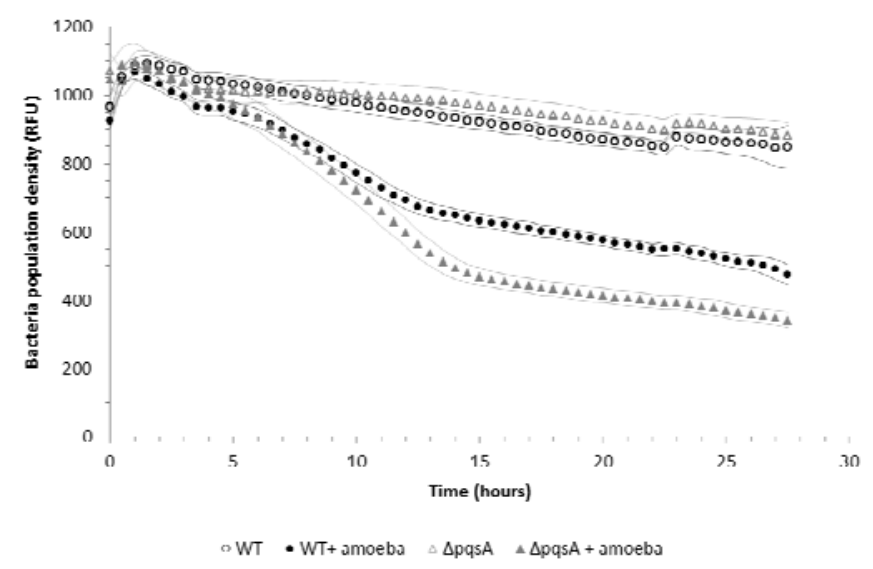

Figure 5 - Predation kinetics of $P$. aeruginosa w.t. and $\operatorname{\Delta pqsA}$. w.t. (black circles) and mutant (grey triangles) fluorescence was measured over 27 hours in the presence (full) and absence (empty) of amoebae. $\mathrm{n}=14$ for all treatments, flanking curves represent $\pm 1 \mathrm{SD}$.

Survival of bacteria corresponded with their ability to kill amoebae (figure 6), studied using direct microscopy counting of amoebae cocultured with $P$. aeruginosa. Wild type $P$. aeruginosa was able to lyse amoebae while $\Delta p q s \mathrm{~A}$ mutant was only able to reduce amoebae growth, when compared to heat killed wild type. Complete dataset, including different initial culture densities, kinetics over three time points, and amoebae growth in co-cultivation with Escherichia coli (which enable far better amoebae growth) are found in figure S3.

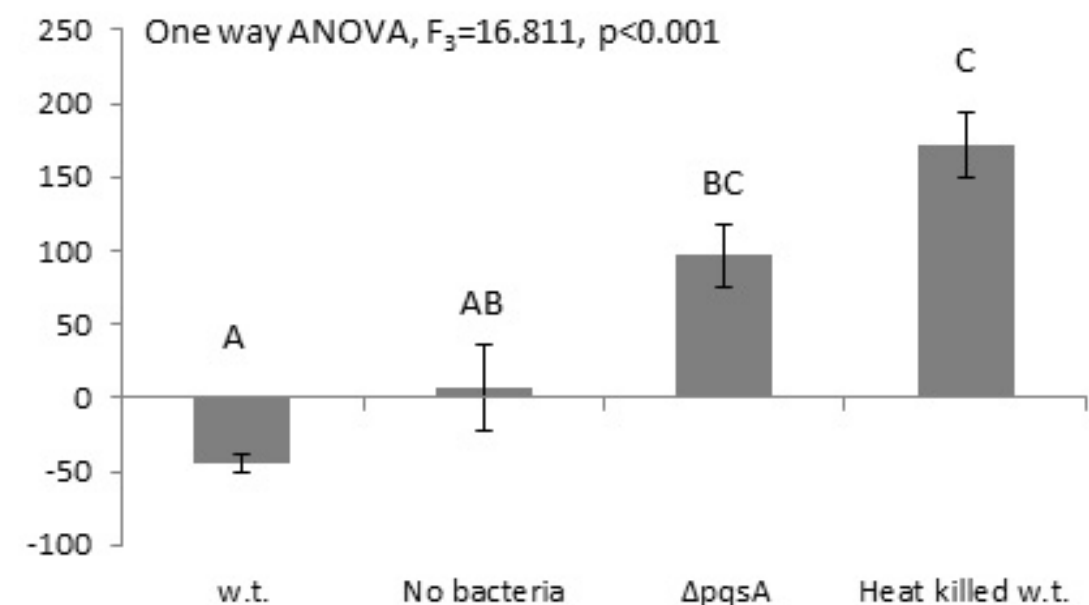

Figure 6 - amoebae survival and growth in co-cultivation with w.t. and $\Delta$ pqsA $P$. aeruginosa bars represent \% change of initial amoebae count in each chamber at 36 hours' time. $n=5$ for each treatment, error bars stand for $\pm 1 \mathrm{SD}$, groups marked with different letters are statistically different. 


\section{Discussion}

Mobbing is a predation avoidance behavior, an attack of prey on predator. If enacted by too few individuals such an attack is likely to fail - predators after all evolved by natural selection to deal with prey. Prey can offset this imbalance by a coordinated group attack. The benefit of mobbing; long term reduction in predation risk, is a common good, shared by all members of the prey community. In contrast, the cost of mobbing; immediate predation risk, is paid only by active mobbing participants. This disassociation between benefits and costs reduces the relative fitness of mobbing participants, unless mobbing behavior is prevalent in the prey community. It is not surprising that mobbing behavior is seen in communicating social animal species[1316], able to generate trust by communicating their willingness to participate in the mobbing effort.

Living is clonal populations that promote kin selection, generating trust by the use of quorum sensing and suffering from predation, mobbing seems a natural course for bacterial evolution. Mobbing, operating in seconds and minutes scale, can buy valuable time, opening the way to slower predation avoidance mechanisms such as formation of microcolonies or anti-predator toxins.

Time-lapse microscopy of $P$. aeruginosa in the presence of amoebae shows bacterial adhesion to predator cells within seconds of their introduction to amoebae. Bacteria display taxis towards predator cells, which they are able to sense using some soluble predator secretion - a predator kairomone [17].

Coordination of mobbing behavior is seems to be facilitated by the PQS system. A mutant unable to produce PQS was found to be unselective in its adhesion behavior and it ability to kill amoebae. Interestingly, mutants of the LAS and RHL QS systems, both employing N-acylhomoserine lactone signal molecules, showed w.t. like amoebae killing, suggesting these signals are not involved in mobbing[8]. Given that the 
379 PQS is almost unique to P. aeruginosa[9] while ASL signals are used 380 by many gram negative bacteria[18], these results demonstrate the 381 importance of a trusted communication, insuring sufficient mobbing 382 participation by competent individuals.

383 The P. aeruginosa-A. castellanii model system described here could be 384 used for the experimental study of behavioral ecology game theory 385 scenarios, enabling easy replication, manipulation and data collection.

386 Microbial ecology is often described only by genetics and metabolism, 387 portraying bacteria as mechanic and passive organisms. This work gives 388 a first impression of bacterial mobbing, a responsive and dynamic 389 behavior. We hope that this, and future of microbes behavioral ecology, 390 may change this view, presenting the true nature of bacteria, as complex 391 and colorful in the micro scale, as our experience of nature in the macro 392 scale. Quod est inferius est sicut quod est superius - as above so below. 


\section{Reference:}

1. Stankowich T. Defensive Risk-Taking in Animals 2 ? In: Choe JC (ed). Encyclopedia of Animal Behavior (Second Edition). 2019. Academic Press, Oxford, pp 340-348.

2. Matz C, Kjelleberg S. Off the hook-how bacteria survive protozoan grazing. Trends Microbiol 2005; 13: 302-307.

3. Jousset A. Ecological and evolutive implications of bacterial defences against predators. Environ Microbiol . 2012.

4. Tuorto SJ, Taghon GL. Rates of benthic bacterivory of marine ciliates as a function of prey concentration. $J$ Exp Mar Bio Ecol 2014.

5. Pickup ZL, Pickup R, Parry JD. Growth of Acanthamoeba castellanii and Hartmannella vermiformis on live, heatkilled and DTAF-stained bacterial prey. FEMS Microbiol Ecol 2007.

6. Mukherjee S, Bassler BL. Bacterial quorum sensing in complex and dynamically changing environments. Nat Rev Microbiol . 2019.

7. Diggle SP, Whiteley M. Microbe profile: Pseudomonas aeruginosa: Opportunistic pathogen and lab rat. $\mathrm{Br}$ Microbiol 2020; 166: 30-33.

8. Matz C, Moreno AM, Alhede M, Manefield M, Hauser AR, Givskov M, et al. Pseudomonas aeruginosa uses type III secretion system to kill biofilm-associated amoebae. ISME J 2008.

9. Diggle SP, Lumjiaktase P, Dipilato F, Winzer K, Kunakorn M, Barrett DA, et al. Functional Genetic Analysis Reveals a 2-Alkyl-4-Quinolone Signaling System in the Human Pathogen Burkholderia pseudomallei and Related Bacteria. 
Chem Biol 2006.

10. Banin E, Vasil ML, Greenberg EP. Iron and Pseudomonas aeruginosa biofilm formation. Proc Natl Acad Sci U S A 2005.

11. Davies DG, Parsek MR, Pearson JP, Iglewski BH, Costerton JW, Greenberg EP. The involvement of cell-to-cell signals in the development of a bacterial biofilm. Science (80- ) 1998.

12. Shteindel N, Yankelev D, Gerchman Y. High-Throughput Quantitative Measurement of Bacterial Attachment Kinetics on Seconds Time Scale. Microb Ecol 2019.

13. Breed MD, Guzmán-Novoa E, Hunt GJ. D EFENSIVE B EHAVIOR OF H ONEY B EES $\square$ : Organization, Genetics, and Comparisons with Other Bees . Annu Rev Entomol 2004.

14. Dominey WJ. Mobbing in Colonially Nesting Fishes, Especially the Bluegill, Lepomis macrochirus. Copeia 1983.

15. Graw B, Manser MB. The function of mobbing in cooperative meerkats. Anim Behav 2007.

16. Arnold KE. Group mobbing behaviour and nest defence in a cooperatively breeding Australian bird. Ethology 2000.

17. Brown, WL, Eisner T, Whittaker RH. Allomones and Kairomones: Transspecific Chemical Messengers. Bioscience 1970. 
bioRxiv preprint doi: https://doi.org/10.1101/2020.06.15.152132; this version posted June 15, 2020. The copyright holder for this preprint (which was not certified by peer review) is the author/funder. All rights reserved. No reuse allowed without permission.

453

454

455

\section{Supplementary 1}

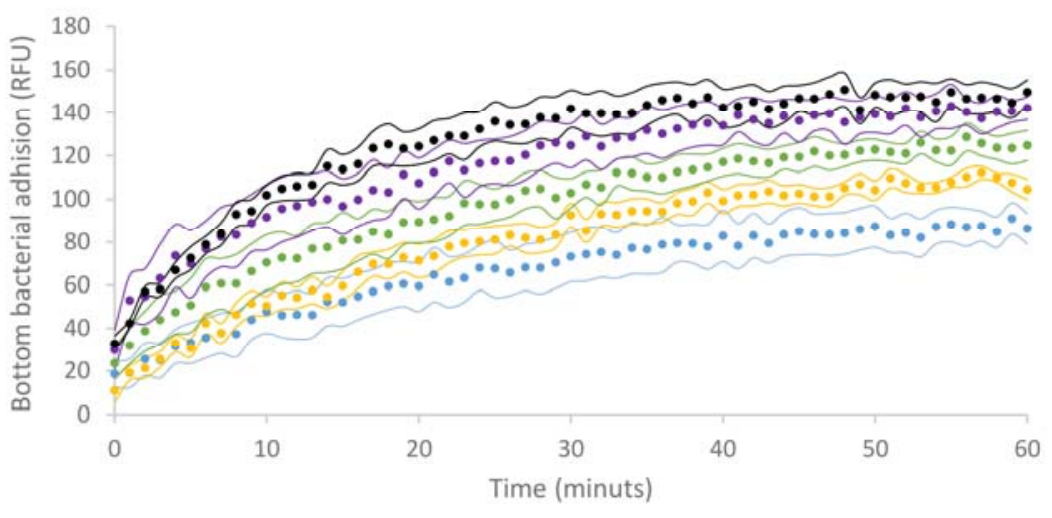

Paramecia/well $\quad \cdot 50 \cdot 25 \cdot 12 \cdot 6 \cdot 0$

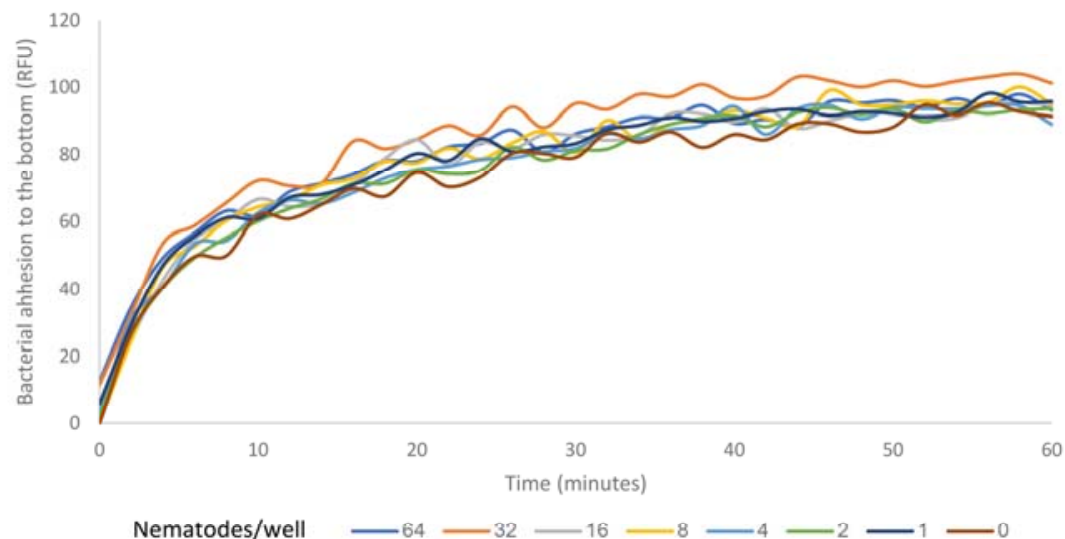

Pseudomonas aeruginosa mobbing behavior towards Paramecia. Sp and Caenorhabditis elegans - Paramecia were separated from wheat grain enrichment culture by filtering, and diluted in dechlorinated tap water. C. elegance were taken from liquid culture and transferred to TBSS. Bacterial suspension used the same medium used in the corresponding predator culture used, added with final

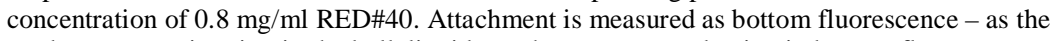
predators are swimming in the bulk liquid attachment cases reduction in bottom fluorescence kinetics as it removes free bacteria from the medium. Changes in bacterial adhesion are in invers correlation to Paramecium population density but no correlation is seen with nematode population density. $\mathrm{n}=7$ for all treatments, flanking curves (when present) indicate $\pm 1 \mathrm{SD}$. 


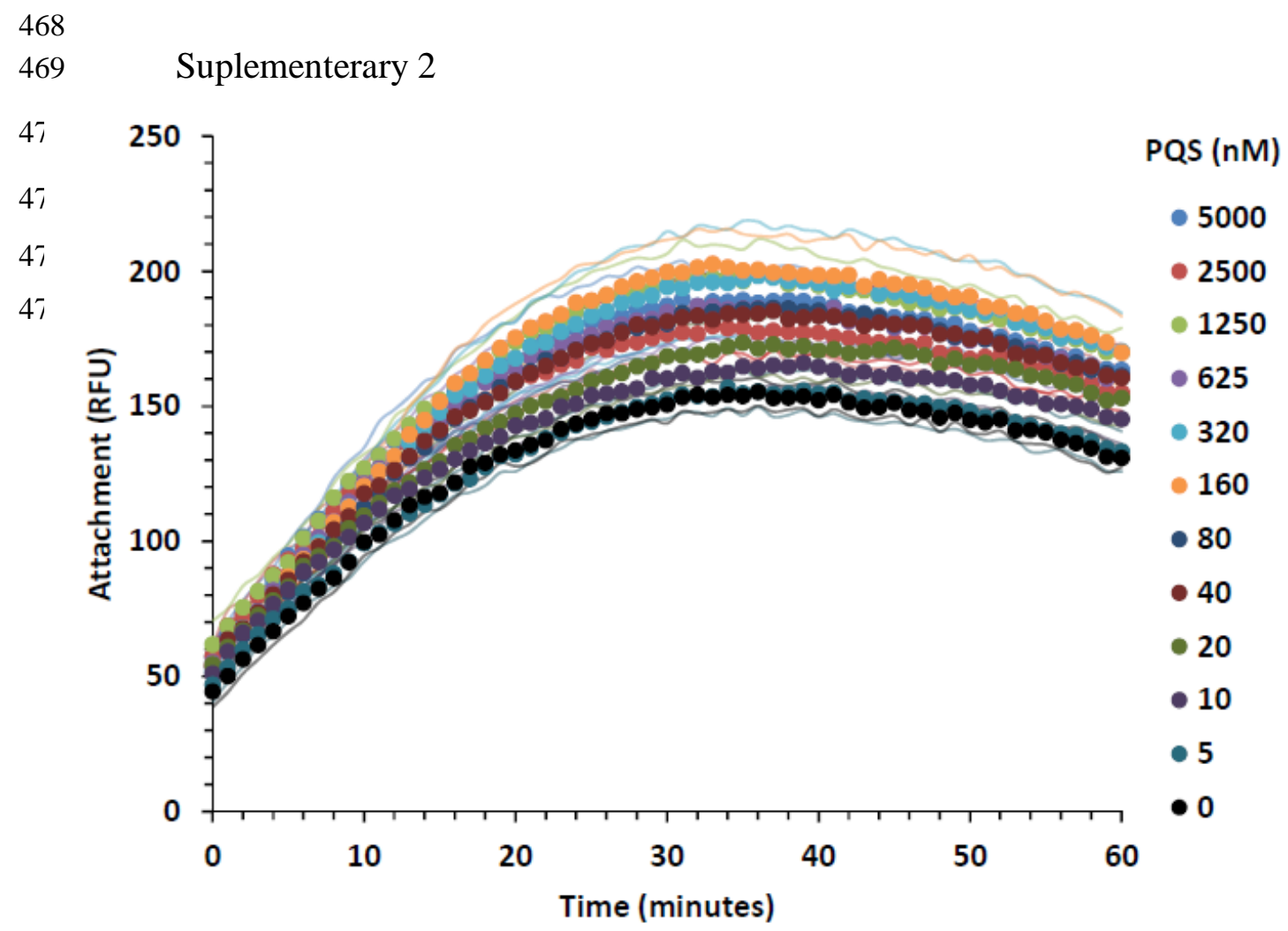

Effect of PQS dose on $P$. aeruginosa $\triangle$ pqsA attachment in the presence of amoebae per well: all PQS concentrations presented; $n=7$; Symbols mark for measurement times; flanking curves signify \pm 1 S.D. 
bioRxiv preprint doi: https://doi.org/10.1101/2020.06.15.152132; this version posted June 15, 2020. The copyright holder for this preprint (which was not certified by peer review) is the author/funder. All rights reserved. No reuse allowed without permission.

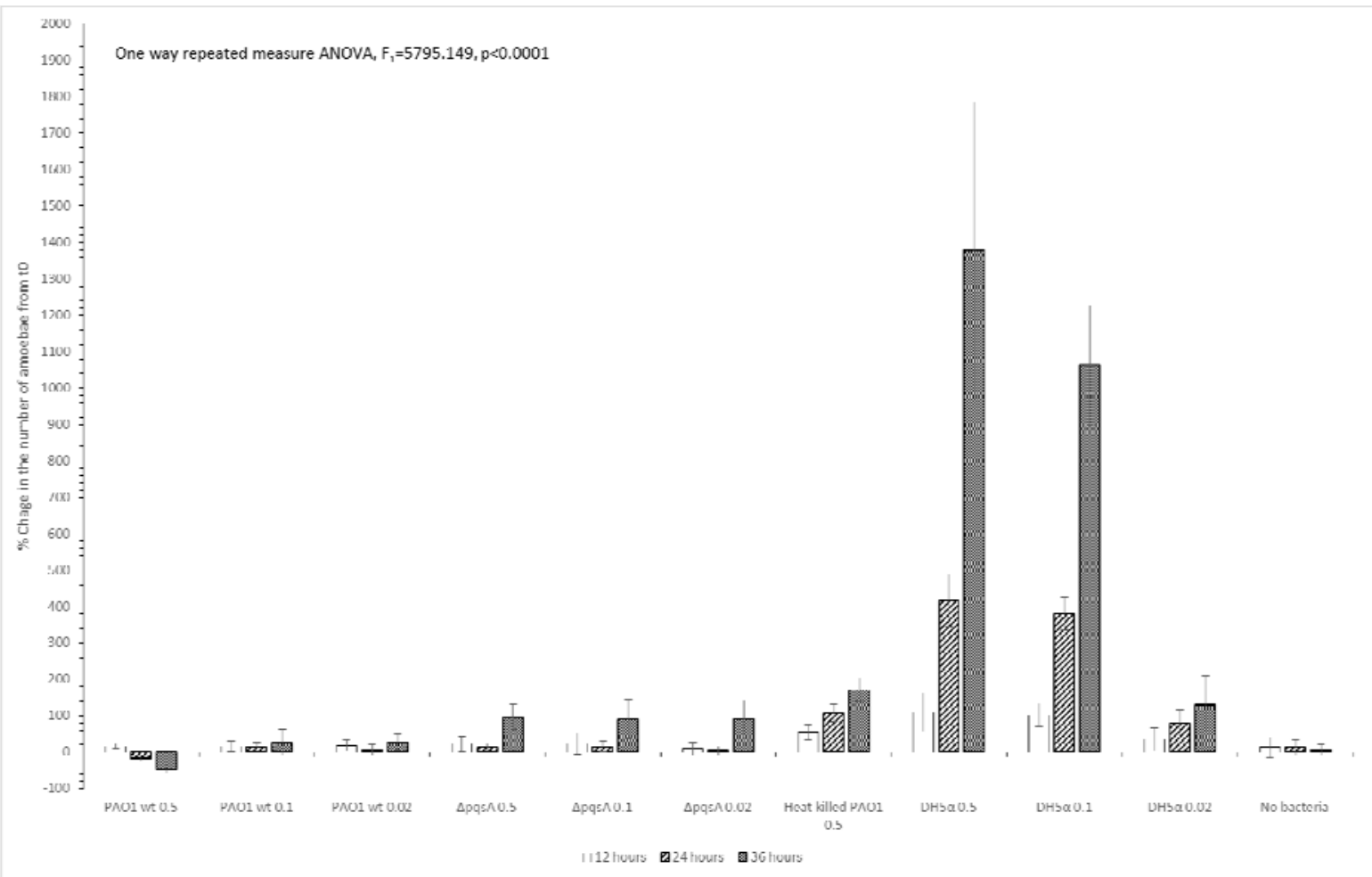

Supplementary 3

Survival and growth of amoebae in co-cultivation with different bacterial strains, starting with different initial culture densities at three measurement times. $n=5$ per treatment, bars stand for $\%$ change in the number of amoebae cells from time 0 , number in category name stand for initial $\mathrm{OD}_{600 \mathrm{~nm}}$ error bars represent $\pm 1 \mathrm{SD}$. All requirements for parametric test were satisfied, Tukey HSD post hoc was applied, results given in the table below.

\begin{tabular}{|c|c|c|c|c|c|c|}
\hline \multirow{2}{*}{ treatment } & \multirow{2}{*}{$\mathrm{N}$} & \multicolumn{4}{|c|}{ Tukey HSD post hoc } & \multirow[b]{2}{*}{ Groups: } \\
\hline & & 1 & 2 & 3 & 4 & \\
\hline PAO1 0.5 & 5 & 0.8508 & & & & A \\
\hline No bacteria & 5 & 1.0493 & 1.0493 & & & $A B$ \\
\hline PAO1 0.1 & 5 & 1.092 & 1.092 & & & $B C$ \\
\hline PAO1 0.02 & 5 & 1.0982 & 1.0982 & & & C \\
\hline ApqsA 0.02 & 5 & & 1.3008 & 1.3008 & & D \\
\hline Apqsa 0.5 & 5 & & 1.3043 & 1.3043 & & \\
\hline ApqsA 0.1 & 5 & & 1.3053 & 1.3053 & & \\
\hline DH5a 0.02 & 5 & & 1.3264 & 1.3264 & & \\
\hline $\begin{array}{l}\text { PAO1 Heat } \\
\text { killed } 0.5\end{array}$ & 5 & & & 1.4122 & & \\
\hline DH5a 0.1 & 5 & & & & 2.2869 & \\
\hline DH5a 0.5 & 5 & & & & 2.5213 & \\
\hline Sig. & & 0.177 & 0.084 & 0.968 & 0.236 & \\
\hline
\end{tabular}


bioRxiv preprint doi: https://doi.org/10.1101/2020.06.15.152132; this version posted June 15, 2020. The copyright holder for this preprint (which was not certified by peer review) is the author/funder. All rights reserved. No reuse allowed without permission.

484

Means for groups in homogeneous subsets are displayed.

Based on observed means.

The error term is Mean Square(Error) $=.019$.

a. Uses Harmonic Mean Sample Size $=5.000$.

b. Alpha $=.05$. 